\title{
Airway Nerve Blocks in Awake İntubation
}

\author{
Semih Başkan*, Dilşen Örnek, Müge Çakırca, Hidayet Ünal, Doğan Atan and Mustafa Baydar \\ Ankara Numune Training and Research Hospital, Turkey
}

Submission: September 19, 2018; Published: September 25, 2018

*Corresponding author: Semih Başkan, Ankara Numune Training and Research Hospital, Turkey, Email: drsemkan@yahoo.com

\section{Abstract}

Awake intubation is one of the strategies which planned according to situation of the patient, surgical procedure, the skill of the anaesthetist, the patient has difficult airway. Flexible fiberoptic bronchoscopy (FOB) is the golden standard for difficult airway patients. Airway reflexes can be removed by performing superior laryngeal nerve block (SLNB) and glossopharyngeal nerve block. Sedation is needed in this procedure to reduce anxiety and adverse events. We report a case that awake intubation assisted with FOB was performed with a bilateral glossopharyngeal nerve block and ultrasound-guided bilateral SLNB who had a difficult airway, scheduled for direct laryngoscopy.

Keywords: Coronary arterial; Anaesthetist; Glossopharyngeal nerve; Glottis; Fibreoptic intubation; Midezolam

Abbreviations: FOB: Flexible Fiberoptic Bronchoscopy; SLNB: Superior Laryngeal Nerve Block; COPD: Chronic Obstructive Pulmonary Diseases; SLN: Superior Laryngeal Nerve

\section{Case History}

The patient was 66 years old, male, smoker (1 box a day for 50 years). He has COPD (Chronic obstructive pulmonary diseases) nearly 30 years and story of coronary arterial diseases. He planned for direct laryngoscopy. İn pre-operative assessment the patient has shortness of breath, hoarseness, cough, phlegm and hemoptysis. Because of a lesion that keeps being more on right vocal cord continuous on anterior commissure, left vocal cord and filled right ventricule holding both band ventricules also extend in the posterior subglottic area about $2 \mathrm{~cm}$, the opening of rima glottis was only $5 \mathrm{~mm}$. Due to a potentially difficult airway, the anaesthetic plan was to perform an awake fibreoptic intubation. We decided to perform glossopharyngeal and superior laryngeal nerve block to anaesthetise for awake intubation.

$\%$ Midezolam, $2 \mathrm{mg}$ and remifentanyl, $50 \mu$ g wereadministered intravenously, and than infusion of remifentany $(0.25 \mu \mathrm{g} / \mathrm{kg} / \mathrm{h})$ was administered intravenously. Block of the lingual branch of the glossopharyngeal nerve was performed using $60 \mathrm{mg}$ of lidocaine $2 \%$ in a syringe with a needle $22 \times 32 \mathrm{~mm}$. The tongue was retracted medially, and the needle was inserted under the mucosa at the base of the pillar, $0.5 \mathrm{~cm}$ lateral to the base of the tongue $30 \mathrm{mg}$ lidocaine were injected in each side. A portable ultrasound machine (USG $6-13 \mathrm{MHz}$ linear probe, Logiq e, General Electric, USA) was brought to the operating room. We scanned neck of patient using with ultrasound. Hyoid bone was easily identified in the transverse plane and prope rotated to sagittal plane. SLN was seen below the level of great hyoid horn. $1 \mathrm{ml}$ of $2 \%$ lidocaine were injected by A 22 gauge needle under ultrasound guidance in an in-plane configuration. This process was applied to the other side and consequently bilateral superior laryngeal nerve (SLN) was blocked. Endotracheal tube(diameter: $5.0 \mathrm{~mm}$ ) passed easily through the vocal cords without triggering a cough reflex, airway compromise rises in blood pressure and heart rate. Correct placement of the endotracheal tube was confirmed with the fiberscope, capnography and auscultation. General anaesthesia was started. Direct laryngoscopy and biopsy performed successfully.

\section{Discussion}

Fiberoptic intubation of the spontaneously breathing patient is the gold standard and technique of choice for the elective management of a difficult airway (Figure 1).

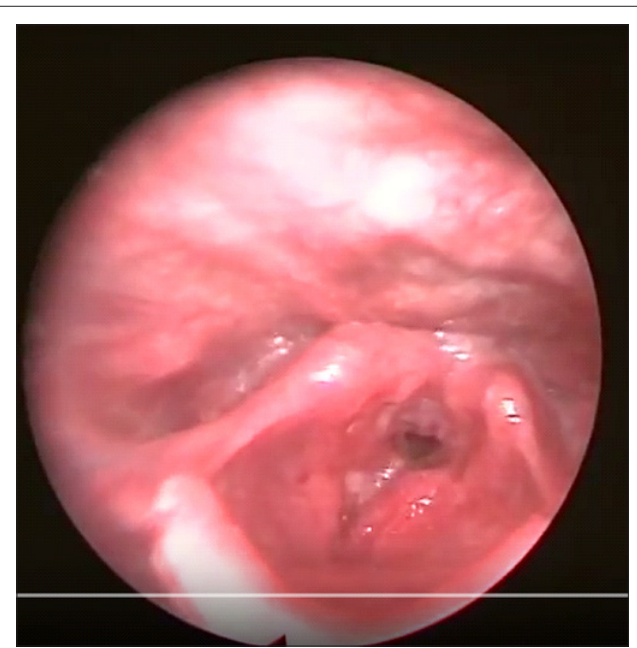

Figure 1: View of Flexible fiberoptic bronchoscopy. 
With SLBN lingual radiks, epiglottis, cricoideal muscule anaesthesia can be achived so cough, retching and straining reflexes eleminated. During awake intubation in patients, sedation is used to relieve anxiety, induce amnesia, eliminate pain and blunt protective reflexes (e.g. cough). Opioids and benzodiazepines are administered intravenously; their doses should be suitably adjusted to avoid excessive sedation and apnoea, which may be life threatening in difficult airway cases. The findings of recent studies demonstrate that remifentanil usage during fibreoptic intubation shortens the procedure and provides higher comfort [1]. Recently, ultrasound guided can be useful and altrenative to identify and assist for superior laryngeal nerve block in patients undergoing awake FOB intubation [2]. This technique can provide good visual information on the anatomy. The potential advantages of using ultrasound imaging for nerve blocks include reduction in the amount of local anaesthetic required, improved success rate, reduced time to perform the block and reduced complication rate [3]. In this case, use of ultrasound made it possible to perform a superior larengeal nerve block with low dose local anaesthetic without complications (bleeding, hematoma, failure block, accidental injection).

\section{Result}

Awake entubation can be performed after performing SLBN and glossofrangeal nerve block with fiberobtic broncoscopy in patients have difficult airway.

\section{References}

1. Mingo OH, Ashpole KJ, Irving CJ, Rucklidge MW (2008) Remifentanil sedation for awake fibreoptic intubation with limited application of local anaestetic in patients for elective head and neck surgery. Anaesthesia 63(10): 1065-1069.

2. Iida T, Suzuki A, Kunisawa T, Iwasaki H (2013) Ultrasound-guided superior laryngeal nerve block and translaryngeal block for awake tracheal intubation in a patient with laryngeal abscess J Anesth 27(2): 309-310.

3. Brain D, Gabrielle I (2009) An estimation of the minimum effective anesthetic volume of $2 \%$ lidocaine in ultrasound-guided axillary brachial plexus block. Anesthesiology 111(1): 25-29.

\section{Your next submission with Juniper Publishers will reach you the below assets}

- Quality Editorial service

- Swift Peer Review

- Reprints availability

- E-prints Service

- Manuscript Podcast for convenient understanding

- Global attainment for your research

- Manuscript accessibility in different formats

( Pdf, E-pub, Full Text, Audio)

- Unceasing customer service

Track the below URL for one-step submission https://juniperpublishers.com/online-submission.php 